\title{
O ETHOS ATÓPICO
}

\author{
HÉLIO OLIVEIRA ${ }^{1}$
}

RESUMO: Este artigo se dedica a um tema bem pouco explorado: o funcionamento dos discursos atópicos, aqueles caracterizados por um pertencimento problemático ao espaço social, operando nas fronteiras entre o tolerável e o inaceitável. O objetivo principal é identificar e descrever o ethos típico do enunciador do discurso atópico. Os resultados mostram um ethos híbrido instável, constituído de traços fluidos que contribuem para a dissimulação do fiador desse tipo de discurso, caracterizado por uma identidade flutuante.

Palavras-chave: Ethos discursivo; Atopia discursiva; Intolerância.

ABSTRACT: This paper is dedicated to an underexplored topic: the functioning of atopic discourses, characterized by a problematic belonging to the social space, and operating on the boundaries between the tolerable and the unacceptable. The main objective is to identify and to describe the typical ethos of the enunciator of atopic discourse. The results reveal an unstable hybrid ethos with a fluid nature that contributes to the concealment of the enunciator of this type of discourse, characterized by a floating identity.

Keywords: Discoursive ethos; Discoursive atopy; Intolerance.

\section{INTRODUÇÃO: O FENÔMENO DO ETHOS MÚLTIPLO}

A noção de ethos discursivo está longe de ser estável ou de ser imune a transformações e desenvolvimentos, como bem o reconhece Maingueneau (2008a, p.56), no texto "Problemas de ethos", ao apresentar a noção como portadora de uma "vocação interdisciplinar". Um dos pontos desafiadores em relação a esse tema é o ethos que manifesta características conflitantes e até contraditórias, tornando difícil sua identificação. Analisar a convergência de diferentes ethé na constituição de um ethos peculiar, multifacetado, no âmbito dos discursos intolerantes, é o objetivo principal deste artigo.

A primeira dimensão dessa problemática seriam os casos em que o ethos pretendido não é aquele de fato produzido. Maingueneau cita como exemplo o caso do professor que gostaria de ser visto como "sério", e articula seu discurso nesse sentido, mas acaba sendo percebido como "monótono", ou aquele que se esforça para parecer "simpático", mas é visto como "demagogo" (2008a, p. 61). Esse aspecto pode ser considerado resolvido pelo próprio viés epistemológico da

${ }^{1}$ Centro Universitário da Fundação de Ensino Octávio Bastos, São João da Boa Vista, SP, Brasil. helio.sjbv@gmail.com 
análise do discurso: sendo uma categoria discursiva, o ethos não depende, nem está a mercê, da vontade/consciência dos indivíduos (estes mesmos não são "a fonte do sentido", como esclarecem Pêcheux e Fuchs, 1975), mas é uma instância construída no e pelo discurso, independentemente da suposta intenção do falante. Além disso, Maingueneau assinala que "a eficácia do ethos tem a ver com fato de que ele envolve, de alguma forma, a enunciação, sem estar explicitado no enunciado. (...) ele deve ser percebido, mas não deve ser objeto do discurso" (2008a, p. 59).

A segunda dimensão, cuja análise deu origem a este trabalho, aparece na forma de diferentes ethé em um mesmo enunciador. Este fenômeno é ilustrado por Maingueneau com o exame de um cartaz do festival "Les comiques agricoles", realizado em ambiente rural, em meio a pomares, vacas leiteiras, culinária rústica e atrações culturais que abrangem exposição de fotografia e outras artes plásticas, música e dança. Em resumo, a análise mostra que se misturam simultaneamente "traços de ethos de mediador cultural e de ethos rural convencional" (2008a, p. 69). Alguns detalhes são acrescentados, pelo autor, à análise desse mesmo cartaz em um texto posterior: "o ethos dessa publicidade permite dar uma consistência imaginária a essa associação improvável de elegância urbana com um retorno ao mundo camponês autêntico" (MAINGUENEAU, 2008b, p. 26). Assim, de forma "composta", o ethos que emerge desse texto publicitário é, ao mesmo tempo, citadino e camponês. As semelhanças e diferenças desse ethos cindido com aquele dos discursos intolerantes também serão examinadas ao longo deste trabalho.

Outros pesquisadores já se debruçaram sobre questões levantadas por esse tipo de ethos "composto". Entre estes, Ferreira (2008) verificou a ocorrência de dois ethé, serenidade e paixão, no discurso neodarwinista, enquanto Miqueletti (2008) observou que o enunciador do discurso político tucano transita entre conservadorismo e modernidade. Entretanto, o enunciador dos discursos intolerantes (atópicos) apresenta uma natureza diferente dos casos citados. O discurso político pode ou não recorrer ao ethos múltiplo, da mesma forma que o discurso neodarwinista, o discurso publicitário e o discurso filosófico podem ou não se valer desse tipo de ethos (por exemplo, Maingueneau [2008b] atribui a um texto específico de Althusser a categoria de ethos híbrido, todavia isso não é recorrente em todos os textos do filósofo marxista).

Diferente das análises citadas até agora, a tese aqui defendida é a de que os discursos atópicos sempre recorrem ao ethos de tipo híbrido, pois essa "apresentação de si" ambígua seria parte constitutiva da atopia discursiva. A partir desse pressuposto, pretende-se mostrar quais são as particularidades do que passamos a chamar de ethos atópico, utilizando como base um corpus reunido em torno de declarações polêmicas que causaram comoção e circularam por jornais impressos, blogs e portais jornalísticos porque foram entendidas como discurso de ódio, intolerância, racismo etc. - aqui considerados no bojo mais abrangente dos discursos intolerantes. 


\section{OS DISCURSOS INTOLERANTES E A ATOPIA DISCURSIVA}

No quadro da tipologia dos discursos, a noção de atopia discursiva foi proposta por Maingueneau como uma espécie de "produção clandestina, noturna, que penetra nos interstícios do espaço social" (2010, p. 166). Ele cita como principal exemplo o caso do discurso pornográfico, além de outras práticas verbais como certos ritos de feitiçaria, missas negras, palavrões, práticas racistas, entre outras, que "são constantemente atestadas, mas silenciadas, reservadas a espaços de sociabilidade muito restritos ou particulares" (p. 166).

Enquanto os discursos tópicos (do grego topos = "lugar"), como o científico e o publicitário, são reconhecidos e "têm direito de cidadania", os atópicos não podem ser "aceitos", nem legitimados. Tomando como exemplo o caso do racismo, não se encontra um "estatuto/manual do racista", uma autodenominada "revista do racista" e qualquer instituição (ou mesmo uma personalidade do meio artístico, político ou intelectual) que aceite ou assuma essa denominação ${ }^{2}$, a despeito dos cotidianos relatos de racismo. Esse é o mesmo caso, no contexto pornográfico, de práticas como a pedofilia - todos sabem que ela existe, mas não é possível que seja aceita em uma sociedade tal como se concebem as relações sociais atualmente. Isso não significa que o racismo e a pedofilia estejam fadados ao banimento e acabarão desaparecendo com o passar do tempo. Muito pelo contrário, essa suposta invisibilidade é o que os torna perenes: os discursos atópicos se nutrem desse não-pertencimento ao dito mundo aceitável para continuarem existindo.

Em Oliveira (2018) propõe-se e explora-se a interpretação de que o discurso racista seria o exemplar prototípico da atopia discursiva. A análise em curso pretende incluir outras formas de intolerância, de discriminação e de discurso de ódio na seara dos discursos atópicos por meio da identificação de um ethos comum a todos esses discursos. Como o conjunto de declarações públicas ofensivas que será analisado abrange um amplo espectro de discriminações (contra negros, contra gays, contra portadores de síndrome de Down, contra movimentos sociais, contra partidos políticos, contra intelectuais e até contra a soberania do Supremo Tribunal Federal), todas essas formas de violência serão consideradas, a partir de agora, sob a denominação mais genérica de discurso(s) intolerante(s), geralmente grafado no plural, tendo em vista sua virtual gradação, que vai desde formas mais ou menos sutis de intolerância, travestidas de "gosto/opinião pessoal" (rir ou contar piadas de deficientes, de pobres, de gordos; trocar de assento em um transporte caso sente

\footnotetext{
${ }^{2}$ Ressalte-se que mesmo entre os chamados "supremacistas brancos" muitos recusam a pecha de racistas ou intolerantes. Em entrevista recente, um deles declarou que prefere o termo "alt-right" [direita alternativa] (entrevista com Spencer Richard, disponível no jornal O Globo, disponível em: https://goo.gl/e9BmXX , acesso 10/03/2019). Em vez de xenófobos e racistas, eles se declaram "nacionalistas", pois, segundo eles, se opõem às políticas de imigração para "proteger" os empregos dos "cidadãos originais" do país, e se opõem à suposta ideologia multiculturarista para "proteger" sua própria "cultura" (geralmente os "valores tracionais", conservadores). Uma ínfima minoria se assume intolerante. Muitos destes, ainda assim, quando o fazem, tentam se retratar. Um caso exemplar é o recém eleito presidente brasileiro, J.Bolsonaro, que havia declarado publicamente ser favorável à tortura e ser homofóbico (entre outras amoralidades) e, atualmente, depois de ser colocado na presidência, alega ser contra a tortura e não ter absolutamente nada contra os gays.
} 
ao seu lado um negro ou um gay; deixar um recinto caso ali chegue um judeu, um muçulmano, um umbandista) até formas mais concretas de discurso de ódio (incitação ao linchamento, ao suicídio, apologia ao genocídio, à xenofobia, atos anticonstitucionais, atentados à democracia etc.).

À guisa de definição, Barros (2015) observa que

os discursos intolerantes são fortemente passionais, seus sujeitos são quase sempre sujeitos apaixonados e predominam, nesses discursos, dois tipos de paixões: as malevolentes (antipatia, ódio, xenofobia etc.) [...] e as paixões do medo do 'diferente'.[...] Trata-se de ações apaixonadas de vingança ou de revolta, que se distinguem da justiça desapaixonada” (2015, p. 64).

Em relação ao enunciador desses discursos, Barros (2016), na esfera da semiótica discursiva, o denomina de "ator da enunciação excessivo". A autora o caracteriza como

um ator da enunciação que podemos chamar de excessivo, em oposição aos insuficientes ou aos que estão na justa medida. A linguagem do exagero, da hipérbole, do palavrão opõe-se à do comedimento, da elegância, da cortesia, que definem a justa medida nos discursos. [Ele] se caracteriza por ser completamente "passional, sem medidas no exagero" (2016, p.21).

Esse "enunciador do excesso" parece ser típico dos discursos de ódio, em sua forma mais explícita, como nas declarações de grupos de "supremacia branca" e de franca apologia ao estupro - e nisso ele se distancia do enunciador atópico prototípico. No trabalho citado há pouco, Barros discorre sobre blogs que orientam jovens universitários a praticarem estupros:

Isto mesmo, filho da puta, com uma mão no pescoço da vadia, vá deslizando a faca pelas pernas dela. Neste momento geralmente a garota começa a chorar. Começa a implorar e a balbuciar em lágrimas. Não dê uma foda para o que ela disser, apenas lembre-se das vezes que foi simpático com vagabundas deste tipo e elas te desprezaram. Agora, agora o jogo mudou, quem está no controle da situação é você e não ela (excerto coletado em BARROS, 2016, p. 15).

Com a análise desse e de demais excertos, a linguista semioticista traça o perfil do "ator da enunciação excessivo" como veiculador de propostas criminosas que aponta para uma fonte cujo responsável deve responder judicialmente e cumprir a pena cabível, quando identificado oficialmente (encontrar um responsável costuma ser bem difícil, pois esses blogs são itinerantes e não dispõem de hospedagem fixa, além de serem mantidos por um perfil falso). Esse exemplo serve para ilustrar a diferença entre o funcionamento tópico do discurso de ódio (identificável como crime) e o funcionamento da dissimulação presente na atopia discursiva (raramente reconhecida como um caso imputável de discurso de ódio, conforme veremos adiante).

Outro caso ilustrativo é, por hipótese, um empresário dizer abertamente que não vai contratar funcionários negros para sua empresa, pelo fato de serem negros. Essa declaração não é fragmento de discurso atópico, é crime de racismo qualificado. Não há funcionamento da atopia nesses casos, portanto, o enunciador dessa declaração é aquele do excesso ("movido pelas paixões", tal como o qualifica a semiótica) e não um representante do ethos atópico. 
O enunciador dos discursos atópicos, diferentemente, se apresenta "na pele" de bom cidadão (ou de "cidadão de bem", como se autodenomina), aceito pela sociedade em geral, defensor das liberdades e da justiça social, a despeito de também cometer atos inaceitáveis, do ponto de vista moral, ético, e até mesmo legal, embora dificilmente se consigam "provas" suficientes para condenação. Entretanto, a atopia não torna o discurso de ódio aceitável, no sentido de tornálo juridicamente inqualificável - a contribuição da análise do discurso seria justamente demonstrar que, embora "escamoteado", o discurso de ódio em sua forma atópica continua sendo moral, ética e legalmente inaceitável. É por essa razão que o "cidadão de bem", enquanto enunciador atópico do discurso de ódio, sempre se desculpa, se justifica ou tenta "explicar" o que disse de forma a não ser visto como um agressor-racista-homofóbico-intolerante. A ambiguidade de sua posição atópica permite que ele se arvore contra o "mal", alegando inocência ou posando de vítima ao mesmo tempo em que agride os outros, incita a violência e fere a democracia. É com essa espécie de personalidade bipolar que emerge a "corporificação" desse enunciador na forma de um "fiador", ou seja, de uma instância discursiva portadora de "um conjunto de determinações físicas e psíquicas" manifestas como "caráter" e "corporalidade" (MAINGUENEAU, 2008b, 18).

No caso do fiador atópico, há outra grande diferença entre ele e o enunciador do discurso do excesso: este último não nega a violência de suas práticas, sejam elas físicas ou verbais. Por esse motivo, em análises da atopia discursiva, é preciso considerar não só os enunciados entendidos como intolerantes, mas também as declarações que equivalem a justificativas/desculpas visando à (tentativa de) dissimulação da intolerância. O processo de justificação pode aparecer de diversas formas, que veremos logo a seguir, e pode ser enunciado pelo mesmo enunciador ou por outra fonte que lhe represente, por exemplo, seu advogado.

Passemos, então, a essa atópica apresentação de si.

\section{DR. JAKYLL E MR. HYDE: UM FIADOR PARA OS DISCURSOS ATÓPICOS}

Algumas observações prévias: na análise de cada ocorrência, conforme antecipado, haverá um excerto que corresponde à declaração compreendida como intolerante, seguido de outro excerto, às vezes coletado na mesma fonte, às vezes em fonte distinta da primeira, representativo da explicação/justificativa/glosa. Mesmo quando se mencionam os nomes próprios "Marília Castro Neves", "Jair Bolsonaro", "Raquel Dodge" etc., é preciso deixar claro que não se trata dessas pessoas enquanto cidadãos no mundo, mas sim enquanto representação discursiva materializada na forma de um enunciador/fiador do dizer. Muito evidentemente, a posição que ocupam como atores sociais (mulher, homem, desembargadora, deputado etc.) investe o dizer de significações que abrangem as instituições e a História - dimensões socio-históricas importantes, mas que é preciso restringir aos limites deste trabalho. Pelo seu caráter propositivo, a análise se restringe a 
apenas alguns aspectos do material apresentado, isto é, àqueles que dizem respeito especificamente aos traços concebidos como identificadores do ethos atópico.

Dentre os traços constitutivos do ethos atópico ora proposto, destacam-se três aspectos principais: a simultânea autovitimização aliada à culpabilização de outrem; a incorporação instável em que é virtualmente impossível caracterizar o fiador em um mesmo campo de adjetivação (ele é predicado com adjetivos distintos entre si e até contraditórios); e a explicitação da violência em maior ou menor grau, por meio de metáforas bélicas, hipérboles que incidem sobre ações violentas, ofensas, humilhações etc.

\subsection{Autovitimização e culpabilização de outrem}

O primeiro caso analisado contempla dois comentários e seus desdobramentos, postados pela mesma pessoa no Facebook. Um se refere à professora Débora Araujo Seabra de Moura, portadora de síndrome de Down, e o outro faz referência ao deputado Jean Wyllys (PSOL-RJ), assumidamente gay e defensor de causas da comunidade LGBTQ+. A autora das postagens, a desembargadora Marília Castro Neves Vieira, do Tribunal de Justiça do Rio de Janeiro, emitiu respostas depois que seus comentários alcançaram grande publicização, e até mesmo uma carta de desculpas três anos após as primeiras ofensas, feitas em meados de 2015.

(1) (Marília) Voltando para casa e, porque vivemos em uma democracia, no rádio a única opção é A Voz do Brasil... Well, eis que senão quando, ouço que o Brasil é o primeiro em alguma coisa!!! Apuro os ouvidos e ouço a pérola: o Brasil é o primeiro país a ter uma professora portadora de síndrome de down!!! Poxa, pensei, legal, são os programas de inclusão social... Aí me perguntei: o que será que essa professora ensina a quem???? Esperem um momento que eu fui ali me matar e já volto, tá? ${ }^{3}$

(2) (Marília) - Eu, particularmente, sou a favor de um "paredão" profilático para determinados entes... O Jean Wyllys, por exemplo, embora não valha a bala que o mate e o pano que limpe a lambança, não escaparia do paredão...

(comentário de internauta) - Quanto ao paredão, de costas, ele amaria. (Marília) - Tenho dúvidas... o projétil é fininho... ${ }^{4}$

(3) (Marília) A questão é a seguinte: a esquerda é dona de um mau humor profundo. (...) Eu não sugeri nada de morte dele [Jean Wyllys]. Meu amigo é que sugeriu que se houvesse... porque naquela época, tem uns três anos, se discutia intervenção militar, começaram a falar de intervenção militar, se os militares voltassem, o que

${ }^{3}$ Texto não assinado. Desembargadora agora ataca professora com Down, mas recebe resposta irretocável. Pragmatismo Político. 20 mar. 2018. Disponível em: < https://goo.gl/E8j7Yf $>$, acesso em 02/03/2019.

${ }^{4}$ RODAS, Sérgio. Sugestão de executar Jean Wyllys foi brincadeira, diz desembargadora do TJRJ. Conjur. 25 jan. 2019. Disponível em: < https://goo.gl/kgFNEx $>$, acesso em 02/03/2019. 
iriam fazer. E esse meu amigo, de brincadeira (...) falou 'mas quem você acha que seria fuzilado?'. Aí eu falei, de brincadeira também: 'Quem não escaparia de um fuzilamento profilático eu acho que seria o Jean Wyllys'. Mas só isso. Não sugeri que ele fosse morto. (...) Ele viu nisso uma forma de se promover, porque ele disse coisas muito piores de outras pessoas. (...) Ele cuspiu na cara do Bolsonaro! ${ }^{5}$

(4) (Marília) Estou escrevendo para agradecer a carta que você me mandou e the dizer que suas palavras me fizeram refletir muito. Bem mais do que as centenas de ataques que recebi nas últimas semanas. Desculpe a demora, mas eu precisava desse tempo. Tenho sofrido muito desde que fui atropelada pela divulgação de comentários meus, postados em grupos privados (...). Perdão, Débora, por ter julgado, há três anos atrás, ao ouvir de relance, no rádio do carro, uma notícia na Voz do Brasil, que uma professora portadora de Síndrome de Down seria incapaz de ensinar. (...) Estendo esta reflexão ao deputado Jean Wyllys. Sempre me oporei às suas ideias e às do PSOL, nada mudará isso, mas é evidente que não desejo mal a ninguém. ${ }^{6}$

O estudo não se concentrará nas declarações ofensivas propriamente ditas, que aqui são apresentadas principalmente à guisa de contextualização dos eventos, mas sim nas tentativas de justificá-las. Dirigindo, então, a atenção às passagens em (3) e (4), desdobramentos dos enunciados em (1) e (2), o primeiro aspecto digno de nota é culpabilização de outrem pelo caráter ofensivo dos comentários ou pelo fato destes terem se tornado polêmicos.

Em (3), figuram como virtuais culpados "a esquerda" (que seria dona de um "mau-humor profundo", portanto, incapaz de perceber a "brincadeira"), um "amigo" (é ele quem haveria sugerido a morte do deputado, ainda que em tom jocoso), a informalidade do contexto em que a postagem foi feita (o tópico da conversa seria outro: a volta do regime militar e suas consequências, a partir da qual a menção a Jean Wyllys teria sido periférica, acidental, o que, segundo essa perspectiva, tornaria possível inferir que não houve "intenção" de atacar o deputado, em uma aparente tentativa de minimizar a apologia ao homicídio) e, por fim, o próprio deputado seria culpado pela controvérsia, pois, segundo Marília, "ele viu nisso uma forma de se promover". Soma-se a essa culpabilização de outrem a estratégia do argumentum ad hominem, atacando a moral do acusador (Jean seria um aproveitador em busca de autopromoção e teria moral duvidosa por "cuspir em Bolsonaro", aludindo a outra polêmica não relacionada ao fato em discussão), o que comprova a diluição da responsabilidade da autora da declaração em prol de fatores externos, alheios à postagem propriamente dita. Nada se diz a respeito do caráter homofóbico presente na alusão ao deputado ser morto de costas, no excerto (2) e do comentário de Marília sobre o projétil "ser fininho", em uma referência de natureza sexual, fálica, relacionada ao imaginário gay e

${ }^{5}$ Idem nota 3.

${ }^{6}$ SOARES, Ingrid. Desembargadora pede desculpas a professora com down e a Marielle Franco.

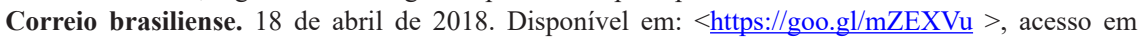
02/03/2019. 
seus estereótipos (sexo anal [posição "de costas" no paredão], desejo de órgãos sexuais avantajados, promiscuidade etc.). Segundo essa perspectiva, a afirmação de "brincadeira" deveria servir para justificar também a homofobia.

Em (4), a resposta segue outro percurso argumentativo, embora guarde semelhanças em termos de posicionamento discursivo. Aparentemente, a postagem em (1) causou grande comoção nos internautas - e rejeição da autora - especialmente devido ao fato de o alvo do comentário ser uma professora em exercício de suas funções, portadora de síndrome de Down. O excerto em (4) é fragmento de uma carta pessoal, escrita por Marília quase três anos depois da postagem no Facebook, como uma espécie de pedido de desculpas. Todavia, essa carta não parece motivada pela ofensa praticada, pois um arrependimento legítimo talvez tivesse levado a desembargadora a escrevê-la logo depois da ofensa original, e não depois de tanto tempo, quando o caso ganhou as mídias. Indícios permitem inferir (conforme apontam os jornalistas citados nas notas de rodapé) que a resposta da desembargadora foi motivada por processos que ela vem respondendo (essa inferência é confirmada na carta pela menção a outras ofensas no mesmo "pedido de desculpas", estendido a Jean Wyllys e à memória de Marielle Franco, também alvos das declarações de Marília) e também por ter chegado a público, algumas semanas antes dessa resposta, uma carta escrita pela professora Débora, intitulada "Recado para a juíza Marília", em que a docente defende seu trabalho como professora auxiliar, afirmando ser preciso "acabar com o preconceito, porque é crime". Mesmo pedindo "perdão" de maneira explícita, a culpabilização de outrem e a autovitimização não deixam de acontecer. Figuram no enunciado em (4) aspectos que parecem vitimizar Marília, que alega ter recebido "centenas de ataques", ter "sofrido muito" e ter sido "atropelada" pela divulgação dos comentários - observe-se que o acento é posto sobre a "divulgação do comentário" e não sobre o fato de ela ter feito o comentário, além do fato de a postagem ter sido feita em "grupos privados", o que sugere que houve quebra de sigilo das postagens dela, que jamais deveriam ter vindo a público, como se o fato de fazer algo ilícito às escondidas minimizasse a infâmia. De modo geral, ações feitas às ocultas costumam despertar ainda mais dúvidas quanto a legalidade do ato.

Além disso, há certa diluição da culpa pela minimização da força ilocucional esperada de um pedido de desculpas, se se considerar alguns trechos-chave da carta. Primeiro, a introdução em forma de agradecimento: "Estou escrevendo para agradecer", e não para se desculpar. Segundo, no trecho do pedido de perdão: embora o nome da professora apareça na posição de vocativo, o pedido ganha impessoalidade quando o objeto da ofensa não foi Débora, mas sim "uma professora com Síndrome de Down". Em outras palavras, o pedido perdeu concretude quando se diz "Perdão por achar que uma professora com síndrome de Down é incapaz de ensinar" em vez de dizer "Perdão por achar que você é incapaz de ensinar". Em vez de humanizar Débora, colocando-a acima de sua condição física, ela continua sendo entendida como "uma professora portadora de síndrome de Down". Pode parecer uma diferença sutil, mas seria uma oportunidade de considerar Débora enquanto pessoa e, quem sabe, tornar o pedido mais sincero e menos parecido 
com uma peça escrita para figurar como prova (de inocência? humildade?) em um processo. Terceiro, além do texto ser chamado de "agradecimento" logo em seu início, no término é chamado de "reflexão": "Estendo esta reflexão ao deputado Jean Wyllys. Sempre me oporei às suas ideias e às do PSOL, nada mudará isso, mas é evidente que não desejo mal a ninguém". pode-se atribuir ao texto pouca firmeza em sua sustentação enquanto pedido de desculpas. Essa inconsistência quanto à interação encenada pela carta (seria um agradecimento, um pedido de desculpas ou uma reflexão?) dilui sua performatividade enquanto pedido de desculpas. $\mathrm{O}$ quarto e último aspecto, relacionado ao anterior, é o fato de a missiva incluir outras pessoas e outros acontecimentos em uma carta supostamente direcionada à professora Débora (além de Jean Wyllys, a carta alude também à Marielle Franco, do mesmo partido político - vide nota 5).

Há, ainda, a negação peremptória de qualquer "dolo", como em "não sugeri nada de morte dele" e "não sugeri que ele fosse morto". Esse tipo de negação categórica, que em Oliveira (2018) é analisada como uma marca sintáticosemântica da atopia discursiva, aqui permite perceber a contradição entre o ethos dito e o ethos mostrado, à medida que o mesmo enunciador se diz sensível e reflexivo ("suas palavras me fizeram refletir muito", "estendo essa reflexão ao..."), mas se mostra sarcástico e agressivo ao fazer seus comentários homofóbicos logo após (portanto, irrefletidamente) a declaração irônica do internauta sobre o fuzilamento de costas ("tenho dúvidas, o projétil é fininho"). Para Maingueneau, o ethos "resulta da interação de diversos fatores: (...) ethos discursivo (mostrado), mas também os fragmentos do texto nos quais o enunciador evoca sua própria enunciação (ethos dito)" (2008b, p.18), conforme os exemplos que acabam de ser citados. Em virtude dessa associação, o autor afirma que o ethos efetivo resulta da interação dessas instâncias (p.19). Nesse sentido, o enunciador atópico, especialmente no contexto dos discursos de ódio, começa a caracterizar-se como um enunciador cindido, bipolar, cujo caráter se alterna entre ser agressivo e, ao mesmo tempo, não desejar mal a ninguém; ofender sarcástica e irrefletidamente, mas fazer reflexões comedidas, em um ciclo constante de "altos de baixos". Observa-se que, na ocorrência do ethos atópico, essa bipolaridade é explorada ao extremo e, assim, constitutiva de um tipo de enunciador que ofende e se desculpa repetidamente.

\subsection{Incorporação instável}

Embora o fiador atópico se mostre bipolar em algumas circunstâncias, sua identidade não se restringe a dois polos opostos numa escala entre "bem" e "mal" ou "virtuoso" e "imoral". Em muitos casos, é virtualmente impossível atribuir-lhe uma caracterização precisa, do ponto de vista da percepção que o "auditório" (os enunciatários) faz dele, pois sua adjetivação é variada. Vejamos como esse aspecto funciona, analisando os excertos a seguir. Estes giram em torno das declarações do então candidato à presidência Jair Bolsonaro, feitas em uma palestra no Clube Hebraica do Rio de Janeiro, em abril de 2017, e alvo de um processo por racismo, no contexto do qual se manifestaram Raquel Dodge, procuradora geral 
da República, bem como Alexandre de Moraes, ministro do Supremo Tribunal Federal, além dos advogados de defesa de Jair Bolsonaro.

(5) J. Bolsonaro: "Eu fui num quilombo, o afrodescendente mais leve lá pesava sete arrobas. Não fazem nada! Eu acho que nem para procriador ele serve mais. Mais de R\$ 1 bilhão por ano é gastado com eles".?

(6) De acordo com a procuradora geral da República, Raquel Dodge, Jair Bolsonaro "usou expressões de cunho discriminatório, incitando o ódio e atingindo diretamente vários grupos sociais". ${ }^{8}$

(7) Segundo sua defesa, Bolsonaro afirma que "não incitou nem induziu plateia, apenas manifestou opiniões, em diálogo com os eleitores. Não existia a mínima possibilidade de [ele] perpetrar tais crimes, porque a plateia (...) entendeu de plano o sentido crítico e jocoso da mensagem. O uso da unidade de medida 'arroba' para se referir ao peso dos quilombolas (...) se trata, tão somente, de uma hipérbole, voltada a enfatizar o discurso, e não a menosprezar ou discriminar". ${ }^{9}$

(8) "No caso em questão, (...) não me parece que, apesar da grosseria, apesar do erro, da vulgaridade, do desconhecimento das expressões, não me parece que a conduta do denunciado tenha extrapolado os limites da liberdade de expressão qualificada e abrangida pela imunidade material. Não teria a meu ver extrapolado um verdadeiro discurso de ódio, de incitação ao racismo ou à xenofobia", disse Alexandre de Moraes. ${ }^{10}$

Detendo-se nos limites do interesse deste artigo, pode-se identificar uma intensa variação na percepção que se faz do fiador. Maingueneau salienta que a adesão dos "destinatários" é parte vital do funcionamento do ethos: "propus designar com o termo 'incorporação' a maneira como o intérprete - audiência ou leitor - se apropria desse ethos", em outras palavras, o modo como se "assimila um conjunto de esquemas que correspondem a uma maneira específica de se remeter ao mundo", constituindo, assim, "a comunidade imaginária dos que aderem ao mesmo discurso" (2008b, p. 18). O fiador, então, corresponde a estereótipos bem conhecidos da publicidade, do cinema, da literatura etc., como "o velho sábio, o jovem executivo dinâmico, a mocinha romântica” entre outros. Esses traços

${ }^{7}$ Texto não assinado. Bolsonaro diz que intenção de denúncia por racismo é criar fato político.

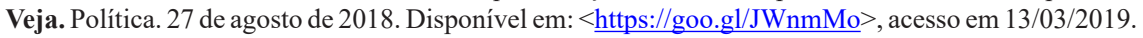

${ }^{8}$ RAMOS, Gabriela. Aqui no Brasil não existe isso de racismo, diz Bolsonaro em Fortaleza. O

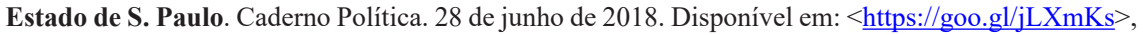
acesso em 13/03/2019.

${ }^{9}$ TUROLLO JR, Reynaldo. Bolsonaro diz ao Supremo que PGR tirou frases de contexto em acusação de racismo. Folha de S. Paulo. Poder. 22 junho de 2018. Disponível em: < https://goo.gl/ $\underline{\text { rsoJGs }}>$, acesso em 13/03/2019.

${ }^{10}$ BARBIÉRI, Luiz Felipe. STF rejeita denúncia contra Jair Bolsonaro por crime de racismo.

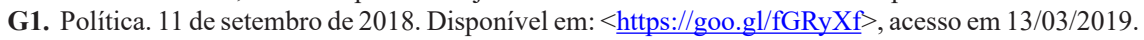


estereotipados são, de certa forma, compartilhados como em uma espécie de osmose entre auditório e fiador.

A ambiguidade da palavra "incorporação", nesse contexto, é explorada por Maingueneau na medida em que significa tanto o processo por meio do qual o auditório "incorpora" (adere ao) o fiador, quanto a fisiologia discursiva que leva o fiador a "incorporar" um estereótipo (embora ele possa ser também "original") e ganhar corpo. Esse duplo processo de incorporação torna-se bastante instável na operação dos discursos atópicos, pelo fato de não haver uma posição fixa (a atopia se caracteriza pelo não-lugar), bem como uma identidade - corporalidade e caráter - fixos. A instabilidade nesse processo de incorporação causa alguns problemas para o fiador atópico, mas, de certa forma, acaba se tornando uma marca identificadora desse enunciador, contribuindo, inclusive, para mantê-lo a salva de sanções diversas, como se verá.

No caso do discurso político evocado pelos excertos acima (o discurso do partido de Bolsonaro, principalmente) é preciso que o fiador político seja, acima de tudo, "incorporável" pelos seus eleitores já declarados (pouco afeitos a cotas raciais, demarcação de terras indígenas e políticas destinadas às minorias sociais), o que parece acontecer em algumas situações (o subtópico 2.3 apresentará outras mais), como nessa passagem em que se zomba de quilombolas (5). Ao mesmo tempo, o fiador político tradicional deve ser também incorporável por eleitores indecisos e até eventuais eleitores da oposição, caso pudessem ver o fiador como alguém "bem-humorado", "jocoso" (7), ou como um orador ousado, que recorre a fortes "hipérboles" para ilustrar suas ideias (7), ou, ainda, como alguém totalmente seguro de si, que tem opiniões fortes e não tem medo de expô-las (8). Ocorre, todavia, que o fiador atópico transita por essas caracterizações e por outras, nas diferentes predicações que vai recebendo (e que vai construindo) conforme entra em contato com posicionamentos discursivos em confronto: intolerante (5), preconceituoso, racista (6), dono das "próprias opiniões" (7), bem-humorado e capaz de um "discurso enfático" (7), vulgar, grosseiro (8), consciente da "liberdade de expressão" (8), ao mesmo tempo em que não é intolerante, nem é racista, nem xenófobo (8). Vale destacar a variação contraditória das concepções que se faz desse fiador: "incita o discurso de ódio e o discriminatório" (6) e "não se enquadra em discurso de ódio nem discriminatório", o que torna fluidos seu caráter e sua corporalidade, dificultando a fixação de sua identidade ${ }^{11}$.

Embora aparente ser um problema, pois a incorporação parece nunca se completar efetivamente, essa instabilidade opera favorecendo o fiador atópico. No caso dos discursos políticos, a opacidade e a identidade flutuante poderiam

${ }^{11}$ No caso específico de Jair Bolsonaro, seu ethos pode ser afetado por "representações prévias" dele que o auditório tem, como é comum em personalidades políticas ou com as chamadas celebridades. Portanto, seu extenso histórico de ataques a mulheres, gays, negros e outras minorias sociais certamente afeta seu ethos atual, no sentido de tentar promover certa estabilização do fiador - o que uma análise mais ampla talvez possa mostrar. No momento, o intuito é apenas somar as declarações dele às de outras figuras, geralmente envolvidas em polêmicas, para tentar estabelecer um possível fiador em comum, tendo em vista a predominância de traços atópicos no discurso em que suas declarações participam. 
favorecer a adesão (na verdade, instigar a adesão, pois, aparentemente, esta não chega a acontecer efetivamente) de um público variado, no qual cada eleitor enxergaria aquilo que "quer" ver (aquilo que a formação discursiva em que se insere lhe permite ver) no candidato. De qualquer modo, a instabilidade no processo de incorporação corresponde ao não-lugar característico dos discursos atópicos, participando da constituição da atopia enquanto fenômeno discursivo.

\subsection{Explicitação da violência}

Parece ser típico dos discursos atópicos "esconder" alguma coisa. Talvez esse seja o próprio modus operandi da atopia: ao praticar algo ilegítimo (segundo uma dada sociedade), torna-se necessário dissimular essa ação. Se, por um lado, a "contravenção" explícita é tópica e, assim, passível de condenação, por outro, sua total opacidade não produz o efeito suficiente para se constituir como um discurso. Isso quer dizer que se o sexismo, o racismo, a homofobia etc. não podem vicejar livremente, tampouco sobrevivem completamente obliterados. Para se constituírem enquanto discurso intolerante, eles necessariamente precisam ofender, discriminar, excluir, agredir...

É nos interstícios desse jogo semântico-discursivo de significar sem significar que vive o fiador atópico. Dissimulado pelos dois funcionamentos anteriores (autovitimização/culpabilização de outrem e incorporação instável), ele se sente amparado para agir.

(9) J. Bolsonaro: “Tem que fuzilar os autores dessa exposição. (...) É uma força de expressão, mas tem que fuzilar". ${ }^{12}$

(10) "Se eleito, eu vou dar uma foiçada na Funai, mas uma foiçada no pescoço. Não tem outro caminho, não serve mais". Na perspectiva de JB o órgão estaria atrapalhando o desenvolvimento econômico do país, o que seria suficiente para extingui-lo. ${ }^{13}$

(11) “A educação brasileira está afundando. Temos que debater a ideologia de gênero e a escola sem partido. Entrar com um lança-chamas no MEC para expulsar o Paulo Freire lá de dentro. A imprensa já falou que eu queria matar gente lá, eu não posso mais usar figura de linguagem". ${ }^{14}$

(12) "Vamos fuzilar a petralhada aqui do Acre. Vamos botar esses picaretas para correr do Acre. Já que gostam tanto da Venezuela, essa turma tem que ir para lá. Só que lá não tem nem mortadela. Vão ter que comer capim mesmo", ressaltou o candidato, que foi ovacionado pelo público. (...) De cima de um trio elétrico,

${ }^{12}$ Texto não assinado. Tem que fuzilar os autores desta exposição, diz Bolsonaro. $\mathbf{O}$ antagonista. 15 de setembro 2017. Disponível em: $<$ https://goo.gl/m8ZGzd $>$, acesso em 13/03/2019.

${ }^{13}$ SILVA, Rafael. Bolsonaro quer abolir Paulo Freire com lança-chamas. Gazeta Online. 01 de agosto 2018. Disponível em: <https://goo.gl/oGrL1Z>, acesso em 13/03/2019.

${ }^{14}$ Idem nota 11. 
o político "empunhou" um tripé de câmera como arma e disparou contra seus adversários petistas. A assessoria do deputado federal destacou que o gesto "foi uma brincadeira, como sempre". ${ }^{15}$

(13) Na entrevista divulgada nesta segunda-feira, Bolsonaro procurou amenizar o tom: "A oposição é boa para você refletir sobre aquilo que por ventura você não esteja fazendo acertadamente." 16

(14) "Temos que tipificar como terroristas as ações desses marginais (...) propriedade privada é sagrada e ponto final. Invadiu, garantindo que é ato ilegal, chumbo". Ele classificou os militantes do Movimento dos Trabalhadores Sem Terra (MST) e do Movimento dos Trabalhadores Sem Teto (MTST) como "vagabundos e marginais". ${ }^{17}$

(15) Em vídeo, o deputado federal Eduardo Bolsonaro (PSL), disse que "bastaria um cabo e um soldado para fechar o Supremo Tribunal Federal", caso houvesse alguma tentativa de impugnação da candidatura do pai dele. (...) O recém-eleito governador Ratinho Junior (PSD) se posicionou a favor de Bolsonaro a partir da campanha de segundo turno, e disse que a fala de Eduardo Bolsonaro não deve "ser levada à sério". ${ }^{18}$

As passagens em que a violência se explicita tornam possível identificar o caráter intolerante do discurso em questão, afastando denominações concorrentes, como discurso humorístico, "liberdade de expressão", "crítica política" etc., embora discriminação e incitação ao ódio possam estar presente em diversos registros e em diversos contextos linguageiros. Na manifestação de violência, o discurso atópico se aproxima da intolerância tópica, explícita, e o fiador atópico posta-se muito próximo do enunciador do discurso do excesso.

Conforme visto previamente, os discursos intolerantes são fortemente passionais, predominando as paixões malevolentes (ódio, xenofobia etc.) e as paixões do medo do "diferente" (BARROS, 2015, já citada). No corpus analisado, aspectos relacionados às paixões malevolentes se manifestam nos ataques explícitos e no uso de expressões beligerantes que remetem à ideia de "guerra", "luta", "batalha", além de verbos ligados à violência física e assassinatos, como “fuzilar”, “exterminar”, “dizimar”, “metralhar”, "usar o lança-chamas”, “usar a

${ }^{15}$ Texto não assinado. Campanha confirma vídeo em que Bolsonaro fala em "fuzilar petralhada

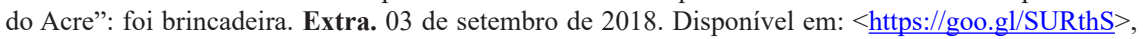
acesso em 13/03/2019.

${ }^{16}$ CAVERNI, Alexandre. Um dia após falar em banir vermelhos, Bolsonaro diz que aceita

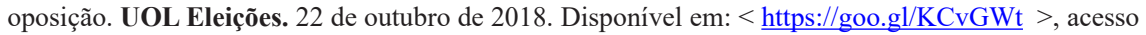
em 13 de março de 2019.

${ }^{17}$ RIBEIRO, Jeferson. Bolsonaro quer tipificar invasão de propriedade por MST e MTST como prática terrorista. O Globo. 21 de maio de 2018. Disponível em: < https://goo.gl/ENtCMN>, acesso em 13 de março de 2019.

${ }^{18}$ Texto não assinado. Chororô e mimimi, diz deputado do PSL sobre fala de Eduardo Bolsonaro. IstoÉ. 23 de outubro de 2018. Disponível em: < https://goo.gl/NbVC3L>, acesso em 13/03/2019. 
foice", "mandar chumbo" etc. O segundo aspecto, o medo passional, implica ações relativamente dissimuladas, que servem para preparar o terreno para as práticas intolerantes explícitas, ou seja, trata-se, muitas vezes, de práticas difamatórias dirigidas à(s) vítima(s) da intolerância no sentido de desqualificar essa pessoa ou grupo por meio de propagação de mentiras, infâmias, ou mesmo de um processo de desqualificação do outro enquanto cidadão (o outro é um "bandido", "mentiroso", "marginal"), chegando a um processo de desumanização (o outro pesa "x arrobas", "não serve nem mesmo para procriar", conforme já visto anteriormente).

Ainda de acordo com Barros, dentre os percursos temáticos que os discursos intolerantes constroem, destacam-se dois: a "animalização do outro", em que são atribuídos traços físicos e características comportamentais de animais, e a "imoralidade do outro", em que se atribui ao alvo da intolerância falta de ética e de civilidade, produzindo a marginalização dessa pessoa/grupo (2015, p. 65). É nesse aspecto que o fiador atópico se aproxima do enunciador do excesso, pois, embora não assuma seu caráter discriminatório, o fiador atópico é, em essência, intolerante. Em (10), a Funai "atrapalha o desenvolvimento econômico do país", em (11), "Paulo Freire" estaria causando o naufrágio da educação brasileira, em (12), os petistas são marginalizados (a sufixação que formou o termo "petralha" evoca a gangue "irmãos Metralha", bandidos retratados em conhecidas HQs), em (14), militantes do PSOL e integrantes dos movimentos MST e MTST são declaradamente nomeados como "marginais" e "terroristas".

O alvo da intolerância sofre sanções de diversas ordens, visando sua parcial ou total exclusão social. Barros assinala que "a sanção pela exclusão é a forma mais intensa e passional" dos discursos intolerantes, tendo em vista que "o medo e o ódio são exacerbados e a oposição semântica [entre "nós" e "os outros"] não admite conciliação ou neutralização" (2015, p. 65). Nesse contexto,

o destinatário da sanção é considerado mau cumpridor de contratos sociais e, na maioria das vezes, excluído do grupo social que o sanciona: julgado mau cidadão, anormal, não-humano, imoral, doente ou feio, o destinatário da sanção é excluído cognitivamente da sociedade e, dessa exclusão cognitiva e afetiva, decorre sua exclusão pragmática, com a punição que recebe. Em outras palavras, ele é afastado do convívio social (não falam mais com ele, é preso, é morto) (BARROS, 2015, p. 65).

Paradoxalmente, a presença de violência é responsável por tornar semelhantes o enunciador do discurso do excesso e o fiador atópico, mas também por distanciálos. A força do fiador atópico vem de sua invisibilidade, de poder atuar nas sombras, de negar o teor violento de suas investidas, enquanto o enunciador do excesso age de maneira explícita, à luz do dia, exibindo sua agressividade e, assim, tornandose um alvo facilmente identificável. Faz parte da fisiologia atópica, então, que a violência seja identificada como alguma outra coisa, aceitável, para que possa se dissimular.

Dessa forma mais ou menos sub-reptícia, o "tom" passa da agressividade à bondade de maneira bastante rápida. É claro que, quando inquirido, o locutor enquanto pessoa no mundo, "responsável" pelo enunciado, nega o caráter negativo de suas declarações e se coloca como defensor do "bem", vítima de difamação ou 
de um mal-entendido. Insistimos, nesse ponto, junto com Motta (2008), que o ethos implica "o que o enunciador mostra de si (ou a imagem que os enunciatários formam do enunciador) a partir de suas práticas discursivas", portanto, não se trata da "vontade pessoal" dos enunciadores, mas sim da "caracterização de suas práticas discursivas" (2008, p. 98).

Em virtude desse funcionamento, o ethos atópico se constrói na ambiguidade de se mostrar violento, ao mesmo tempo em que dilui sua agressividade na "explicação" de que a incitação ao fuzilamento de artistas, autores e expositores (na exposição Queer Museum, promovida pelo banco Santander), que poderia até mesmo ter levado ao linchamento de artistas, é apenas "força de expressão" (9). Da mesma forma, macular as contribuições de um grande educador é "figura de linguagem" (11), simular um fuzilamento é "brincadeira" (12), ameaçar o estado de direito com um golpe militar no STF "não deve ser levado a sério" (14).

Essa dissimulação se reproduz na discursivização do acontecimento: após a declaração inicial, outros dizeres vão se acumulando, atores diversos vão se posicionando contra e a favor, encenando a disputa de forças entre posicionamentos concorrentes, como é comum nas interações polêmicas, diluindo cada vez mais a violência do enunciado original.

O fiador atópico, por sua vez, cumpre seu papel de tornar fluido seu entorno: ele fere e se diz ferido, age com dureza, mas diz ser brincadeira. A alternância de personalidade é tamanha que se chega ao oximoro de dizer que é preciso executar ou banir a oposição política e, logo depois, que "a oposição é boa para fazer você refletir" (13). Nesse contexto específico, por exemplo, o fiador passou rapidamente de ferrenho fascista para um reflexivo e ponderado humanista, demonstrando uma espécie de ethos bipolar, muito semelhante ao protagonista da obra o "O médico e o monstro", de Robert Louis Stevenson (2015 [1886]): em poucos instantes, o gentil e inofensivo dr. Jakyll se transforma no monstruoso e cruel mr. Hyde. Soma-se a esse fato o agravante de que, caso se aplicassem ao fiador atópico, os transtornos catalogados pela psiquiatria, esse enunciador seria melhor classificado como portador de personalidades múltiplas, e não apenas de duas.

\section{CONCLUSÃO: UM ETHOS FUGIDIO}

A aproximação entre a problemática da atopia discursiva e a noção de ethos permitiu identificar o enunciador prototípico dos discursos intolerantes, em sua manifestação atópica. Trata-se de um fiador de difícil caracterização, tendo em vista a própria natureza volátil dos discursos atópicos, mas sobre o qual foi possível esboçar um caráter e uma corporalidade.

Em termos de corporalidade, sua "compleição física" é mutante, algo próximo do protagonista de "O médico e o monstro", à guisa de comparação. O fiador atópico pode corresponder a alguém forte, ágil e poderoso, que ameaça de morte seus oponentes, que empunha fuzis e lança-chamas, e também a um ser frágil e sofrido, eventualmente incompreendido, que "sofre com ataques e críticas", como se lê em um dos enunciados do corpus, e por isso permanece sem 
ação, "atropelado" pelas reações supostamente exageradas a suas declarações - 0 que sugere um corpo apático, prostrado, ao mesmo fiador que há pouco era ágil e poderoso.

Esse fiador peculiar, contudo, não se limita a duas posturas apenas, fraco e forte, bom e mau. Ele assume muitas outras formas, menos descritíveis em contornos corpóreos (a incorporação instável é um de seus traços característicos), mas observáveis em termos de caráter: o mesmo enunciador se apresenta como sarcástico, bem-humorado e muito propenso a "brincadeiras", algumas vistas como vulgares, ao mesmo tempo em que se mostra um crítico contundente da cena política, defende os "bons costumes" e a justiça social por meio de um discurso seguro, com ares de sofisticação, que recorre a hipérboles e metáforas para se fazer entender, e, portanto, seria sério e respeitável - caráter pouco compatível com alguém sarcástico, de linguagem vulgar. Essa contradição se amplia ainda mais nos excertos analisados, nos quais o mesmo fiador é compreendido como responsável por uma ameaça ao Supremo Tribunal Federal e como alguém que "não deve ser levado a sério". Se esse lugar parece insustentável, esse fiador pode ser, então, um homem comum, um vizinho ou um colega de trabalho igual a qualquer outro cidadão, "um filho defendendo um pai", "um brasileiro defendendo a família", "uma amiga de Facebook fazendo uma piada inofensiva", enfim, pessoas e ações totalmente ordinárias, sem vocação para controvérsias, segundo sua própria avaliação e de muitos que entram em contato com esse discurso.

Por meio de várias posturas, de vários modos de habitar o espaço social, o fiador atópico se move praticamente impune das agressões que comete. E é impossível que ele não as cometa, tendo em vista que violentar é a principal razão para ser atópico, para agir "nas sombras".

Diferente dos enunciadores dos discursos neodarwinista, tucano e filosófico, tal como citados no início do texto, o enunciador atópico deve, necessariamente, se apresentar de forma dissimulada, ambígua, pois nisso reside sua identidade.

Diferente do "enunciador do discurso do excesso", que assume publicamente a violência de seus atos, ele não pode se arriscar a ser desmascarado ou deslegitimado, mas deve continuamente realinhar e reenquadrar seu discurso em um contexto moralmente aceitável, valendo-se dos procedimentos típicos dessa posição flutuante: a autovitimização, a culpabilização de outrem e a instabilidade no processo de incorporação (tanto no sentido da dificuldade de ganhar um corpo, de se situar em uma posição, quanto no sentido da adesão do auditório, que não consegue incorporar plenamente aquele fiador, suas máscaras e seu discurso), que servem para nublar aquilo que é inaceitável, daí seu último traço identificador: a violência causada pelas formas disfarçadas de sexismo, racismo, xenofobia, homofobia etc.

O fiador atópico é muito "eficiente" em termos de alcance e de autoreprodução. Como ele segue sempre "aberto" a novas interpretações - efeito potencializado por sua fluidez e opacidade -, acaba tornando infrutíferas as discussões que fomenta, produzindo polêmicas estéreis em torno de temas que merecem discussão aprofundada. 


\section{REFERÊNCIAS}

BARROS, D. L. P. Intolerância, preconceito e exclusão. In: LARA \& LIMBERTI (org) (2015). Discurso e desigualdade social. São Paulo, Contexto, 2015, p. 61-78.

BARROS, D. L. P. Estudos discursivos da intolerância: o ator da enunciação excessivo. Cadernos de estudos linguísticos. (58.1), Campinas, 2016, p. 7-24.

FERREIRA, N. C. Serenidade e paixão: a instabilidade de um ethos na divulgação científica neodarwinista. In: MOTTA, A. R.; SALGADO, L. S. (org) Ethos discursivo. São Paulo: Contexto, 2008.

MAINGUENEAU, D. Problemas de ethos. In: Cenas da enunciação. São Paulo: Parábola Editorial, 2008a, p. 55-73.

MAINGUENEAU, D. A propósito do ethos. In: MOTTA, A. R.; SALGADO, L. S. (org) (2008) Ethos discursivo. São Paulo: Contexto, 2008b.

MAINGUENEAU, D. A paratopia e suas sombras. In: Doze conceitos em Análise do Discurso. São Paulo: Parábola Editorial, 2010, p. 157-170.

MIQUELETTI, F. Tucanos e "mal-entendidos". In: MOTTA, A. R.; SALGADO, L. S. (org) (2008) Ethos discursivo. São Paulo: Contexto, 2008.

MOTTA, A. R. Entre o artístico e o político. In: MOTTA, A. R.; SALGADO, L. S. (org) (2008) Ethos discursivo. São Paulo: Contexto, 2008.

MOTTA, A. R.; SALGADO, L. S. (org) Ethos discursivo. São Paulo: Contexto, 2008.

OLIVEIRA, H. O racismo que (não) se vê: a fórmula "consciência negra" e a atopia do discurso racista brasileiro. Tese (Doutorado em Linguística) - Instituto de Estudos da Linguagem, UNICAMP. Campinas, 2018.

PÊCHEUX, M.; FUCHS, C. A propósito da análise automática do discurso: atualização e perspectivas. In. GADET E HAK (orgs.) Por uma análise automática do discurso: uma introdução à obra de Michel Pêcheux. Campinas: Editora da Unicamp, [1975] 1990.

STEVENSON, R. L. O médico e o monstro. São Paulo: Companhia das Letras [1886] 2015.

Recebido: 15/03/2019

Aceito: 15/06/2019

Publicado: 28/06/2019 